\title{
1. Were the Keynesians loyal followers of Keynes?
}

Tribal warfare is not the most attractive feature of contemporary economics, even if it is much the most exciting. But the vigour of debate occasionally makes it less careful and precise. Distinguished economists become misled by their own slogans and tend to assert glibly what they know should be argued cautiously. One particular vice is the habit of attaching a brand name to a school of thought, not with the intention of designating a common theme, but with that of heightening rhetorical impact. It is right to be suspicious of this tendency because it conveys a possibly spurious impression of unanimity, of a confederation of intellects, which can persuade non-participants in the debate by sheer force of numbers. But there can be a still more serious reason for distrust. When the confederation becomes known by a special name there is a danger that the name can give a distorted idea of the quality of its intellectual weaponry. The danger is greatest when the name used is that of a much revered warrior, now dead, who achieved a number of famous victories in his lifetime.

In economics, the revered warrior in all confrontations is still John Maynard Keynes. A quote from Keynes, no matter how slight and trivial, appears to silence opposition. It has the same force as an appendix of mathematical reasoning or a half-dozen learned articles. It can be a powerful blow in debate and, indeed, it can sometimes serve as a substitute for thought. It is important, therefore, to examine carefully the credentials of any group which calls itself 'Keynesian'. In the 1960s and 1970s the Keynesian label was attached to a body of economists in England, principally from Cambridge University, who held distinctive views on the problem of inflation control. In choosing this label they had - or believed they had - a great advantage. It was then - and remains today - a commonplace that Keynes was worried above all by the depression of the 1930s and the attendant unemployment, and that his work on inflation was insubstantial and can be neglected. The Keynesians therefore had freedom to propound their own views as those of Keynes. This freedom amounted to a licence to counterfeit his intellectual coinage. ${ }^{1}$

In fact, it is not true that Keynes was uninterested in inflation. He lived through the most rapid inflation of the twentieth century: that between 
1914 and 1920, which ravaged the British financial system and devastated the currencies of most European countries. His writings on inflation are extensive. The post-war British Keynesians' views on inflation can be compared with, and checked against, Keynes's own position. It emerges that several leading strands in Keynesian thought cannot be said to have their origins in Keynes's work. The claim of a close correspondence between the two was based on a myth - a myth which was carefully nurtured by a number of economists who collaborated with Keynes in the 1930s, but who outlived him and propagated an influential, but spurious, oral tradition. Tribes, even tribes of economists, need myths. They serve as both emotional support and a sort of shared intellectual cuisine. This particular myth must be exploded. A summary of the Keynesian position is of course needed to define the debate. The account here tries to do justice to Keynesian thought, despite the obvious and unavoidable danger that, by highlighting its central elements, its variety and subtlety may not be sufficiently acknowledged.

\section{I}

The British Keynesians of the 1960s and 1970s saw the inflationary process as almost exclusively a question of 'cost-push'. A number of forces were identified as responsible for rising costs of production throughout the economy and prices were raised in response to higher costs, in order to preserve profit mark-ups. This cost-push process was contrasted with 'excess demand' explanations of inflation, in which the causes were said to be too much demand for labour (which, then, raised wages and costs) and goods (which enabled firms to raise prices without fearing loss of business). Of the forces driving up costs, trade union bargaining pressure (or 'pushfulness') was usually given priority, although rising import costs might also be mentioned. The Keynesians were ambivalent in their attitude to the union movement, because it was regarded as both the cause of a self-defeating jostling between different groups for a higher share of the national cake (which they deplored) and the agent of income redistribution in favour of the lower classes (which they applauded). Nevertheless, they made numerous criticisms of the trade unions and some of them were scathing. At one extreme Lord Balogh - who served as an economic adviser to Harold Wilson, the Prime Minister from 1964 to 1970 - was outspoken and unhesitating in his condemnation. Others were more circumspect. In his contribution to a book on Keynes: Aspects of the Man and his Work (based on the first Keynes seminar which was held at the University of Kent in 1972), Dr Roger Opie - a don at New College, Oxford - attributed their behaviour 
to the economic context in which they operated. It was, he said, the experience of past high employment which had given unions the taste of power, while the combination of organized labour and oligopolized industry had given them the opportunity to exercise it without limit. ${ }^{2}$ Professor Joan Robinson recognized the conflict between the public aims of the labour movement as a whole and the private, self-interested objectives of the individual union. In her view, although the vicious inflationary spiral caused by wage-bargaining did 'no good to the workers', nevertheless it remained 'the duty of each trade union individually to look after the interests of its own members individually' ${ }^{3}$

Accompanying this hostility, open or disguised, to the trade unions, was a set of beliefs about the operation of the labour market. Wages were deemed to be set not by demand and supply, but by bargaining. According to the Keynesians, workers did not move quickly and easily from industry to industry and from firm to firm in response to the incentives of better pay and prospects. The labour market was instead characterized by rigidities and imperfections, and wage determination took place in an environment of 'countervailing power', without respect for fairness or for social justice. ('Countervailing power', was a phrase invented by the American Keynesian, Professor Kenneth Galbraith.) Moreover, the imperfections in the labour market were matched by imperfections in the production and supply of goods. Opie's reference to 'oligopolized industry' was typical. Occasionally even the retailers took their share of the blame. As Sir Roy Harrod put it, the distributors were 'sometimes up to a little mischief'.

In short, the core of cost-push inflation was the conflict between managers, trade unionists and the non-unionized as they struggled endlessly to increase, or at least preserve, their share of the national product. The timing and size of the demands placed on the economy were not thought to have a primarily economic explanation. The principal influences were instead social and psychological, and they operated continuously. The outcome of the distributional struggle was not determined by productivity, but by power, with the strike threat being a crucial determinant.

What, then, was the Keynesians' answer to cost-push inflation? It was direct intervention by the government in the form of prices and incomes policies. The Keynesians were united in this, and in the 1970 s they probably convinced a majority of the academic economics profession in the UK. ${ }^{4}$ Few clearer statements of support can be found than that from Sir Roy Harrod in Keynes: Aspects of the Man and his Work, where he wrote, 'I am myself a definite advocate of what we call an "incomes policy". I believe there must be direct interference'. To the Keynesians a prices and incomes policy served many functions. It was, first and foremost, a weapon to fight inflation. But it was more than that. By enabling a central authority to 
monitor price movements, it superseded - or, at least, overrode - the monopoly bargaining power of large firms and the trade unions. It could thereby contribute to attempts to distribute economic rewards more fairly. Indeed, it could become a means of attaining social justice. ${ }^{5}$

What of the uses of monetary correctives? These were scorned. To quote Harrod again: 'I do not think it is any good saying that banks can stop inflation - saying, let them reduce the money supply. How can the poor banks reduce the money supply? What actually happens is that wage-earners get a demand granted which must raise costs. ${ }^{6}$ If monetary methods had been adopted they would have caused unemployment, and this was thought to be unacceptable. It would have been the negation of Keynesianism if unemployment were the best method of fighting rising prices.

The Keynesian position had the merit of internal consistency. If an economist believed that 'greed' and 'envy' were the causes of inflation, he or she was logical to doubt the efficacy of such indirect methods of control as changes in taxation and interest rates. It was much easier to legislate against greed and envy directly, by laying down statutory limitations on their effects. Keynesianism was also consistent with a particular perception of reality and an associated approach to policy-making. If monopoly power were pervasive, and if markets were stunted by imperfections and rigidities, there was an evident futility in applying remedies which worked on the assumptions of ubiquitous competition and the responsiveness of supply to incentives. But - as we shall see - the Keynesians' position was not consistent with that of Keynes. Their policy prescriptions had no foundation in his written work and were incompatible with fundamental aspects of his economic philosophy.

But surely, it might be said, the Keynesians must have been basing their case on some element of Keynes's thinking. Was there any kinship between their arguments and his? In fact, there was an assumption common both to their way of thinking and the most important part of Keynes's work. It was a technical assumption, slipped into the interstices of the theoretical structure and, for that reason, one whose significance was easily overlooked. It was the assumption in books III and IV of The General Theory of Employment, Interest and Money (1936) that the analysis was to be conducted in terms of 'wage-units'.

Keynes was not concerned in his investigation of unemployment with the relationship between capital inputs and output. The vital relationships were those between employment, output and demand. The function of the wageunit assumption was that it enabled his analysis to focus on these relationships 'provided we assume that a given volume of effective demand has a particular distribution of this demand between different products uniquely 
associated with it'. The wage-unit was defined as the sum of money paid to each 'labour-unit' or, in effect, each worker. ${ }^{7}$ This was a very useful assumption. Keynes could proceed to the determination of output and employment without needing a prior theory of the determination of the money wage and without troubling himself too much over microeconomic details. It might seem to follow that Keynes considered money wages to be given exogenously, perhaps as a result of bargaining.

The subtle effect of the wage-unit assumption on later thinking was noticed in Sir John Hicks's The Crisis in Keynesian Economics. The validity of analysis conducted in wage-units turned on what Sir John calls 'the wage theorem', that 'when there is a general (proportional) rise in money wages, the normal effect is that all prices rise in the same proportion'. ${ }^{8}$ Given the wage theorem, it was immaterial what the particular money wage might be. The relationships between liquidity preference, the investment function, and the rest - the hub of Keynes's economics - were unaffected. Consequently, it became a convenient and innocuous simplification to assume a fixed money wage. Further, the relationship between aggregate demand and the money wage could be neglected.

This chain of thought - or, rather, this compound of faulty thoughthabits and pseudo-empirical hunches - was the source of all the trouble. Keynes made the wage-unit assumption because it facilitated his theoretical task. He could grapple more quickly with the issues of demand and employment, once the awkward (but, to him, supererogatory) problem of money wage determination was put to one side. But this did not mean that he thought money wages were determined exogenously in the real world. Unfortunately, the Keynesians came to think just that. It is almost comical to picture Sir Roy Harrod indulging in an elaborate exegetical hunt - just before an academic conference in the 1970s - to find some justification for his conjecture:

I have searched through his writings very carefully, not long ago - for the purpose of discovering anything he had to say about what we call 'cost-push inflation'. I could find only one short passage in Keynes, just a couple of sentences, where he said . . . Of course the wage-earners might demand more than corresponding to their rise in productivity, might demand more and get more . . You can find those words if you search; I ought to give you chapter and verse, but I have not put down the page reference; they are there all right. ${ }^{9}$

The fact is that Keynes wrote almost nothing about 'what we call "cost-push inflation"'. The 'one short passage' may or may not be a figment of Sir Roy's imagination. The many thousands of words written by Keynes on inflation as an excess demand phenomenon are palpable and, to anyone who 'searches through his writings very carefully', rather obtrusive. 
There are, however, many echoes between the Keynesians' and Keynes's views on social fairness. His writings at times resemble a roll-call of the class structure of a late industrial society, with references to profiteers, rentiers and unions scattered throughout the pages. The passages on income distribution in How to Pay for the War describe the upward swirl of the wage-price spiral particularly well. Here, indeed, it might be said, is the endless social struggle for a higher proportion of the national income. ${ }^{10} \mathrm{But}$ it is difficult to infer Keynes's attitude to the labour movement from his writings. He was certainly alerted to its potential impact on the organization of the markets in factor services. In one of his public speeches he described trade unionists as, 'once the oppressed, now the tyrants, whose selfish and sectional pretensions need to be bravely opposed'. ${ }^{11}$ But the harshness of the observation was unusual. Perhaps it was an isolated piece of bravura intended more for public relations purposes than as an expression in inner conviction. In The General Theory (and elsewhere) the unions are a fact of life; they are not the subject of a favourable or adverse judgement.

\section{II}

But, if there are some reasons for attributing Keynesian views to Keynes's intellectual legacy, there are many more reasons for denying a strong connection between the two. Before moving on to an examination of Keynes's theory of inflation, it is essential to challenge a widespread misapprehension: that Keynes knew nothing about, and was uninterested in, the price mechanism or, more generally, in what we would now call microeconomics. This is simply untrue. ${ }^{12}$ His awareness of the virtues (within limits) of the price mechanism saved him from the common assumption among the Keynesians that official interference to restrain rises in the absolute price level - or, more explicitly, prices and incomes policies - has no damaging repercussions on the configuration of relative prices. He doubted the effectiveness of price controls, with his scepticism based on first-hand knowledge of conditions in the inflation-ridden European economies after the First World War. (He visited both Germany and Russia in the early 1920s.) In The Economic Consequences of the Peace (1919), he wrote, 'The preservation of a spurious value of the currency, by the force of law expressed in the regulation of prices, contains in itself, however, the seeds of final economic decay, and soon dries up the sources of ultimate supply.' A page later he added, 'The effect on foreign trade of price-regulation and profiteer-hunting as cures for inflation is even worse'. ${ }^{13} \mathrm{He}$ derided the 'bread subsidies' which were common at the time. 
Similarly, he regarded centralized control of the wage level as problematic in a democracy. There are recurrent passages in Keynes - particularly when Britain returned to the gold standard (in 1925) - where the need to bring down the level of wages is stressed (if the exchange rate had to be unnecessarily raised). But it was precisely the impracticality of efforts to depress the general wage level which made adjustments of the exchange rate expedient. In 1931, just before Britain left the gold standard, he wrote that the reduction of all money wages in the economy 'if it were to be adequate would involve so drastic a reduction of wages and such appallingly difficult, probably insoluble, problems, both of social justice and practical method, that it would be crazy not to try [the alternative of import restrictions]'. ${ }^{14}$

Of course, the Keynesians could argue in the 1970s - and like-minded people might argue today - that people have become habituated to regulation and control. The improvement in communications has made it that much easier to administer and police a prices and incomes policy. It might be contended that in these altered circumstances Keynes would revise his views, acknowledging some merits in legally imposed limitations on wage and price rises. It is impossible to argue with this. The conjecture might be true, but surely no one can give a definite answer one way or the other. What is clear is that there is nothing in Keynes's writings which explicitly envisages and endorses a prices and incomes policy, and there is much in their mood and tenor which is contemptuous of its makeshift predecessors in the 1920s.

What, then of Keynes's views of the inflationary process? The first point is that Keynes regarded inflation as an excess demand phenomenon. There is very little, if anything, in his writings to suggest that he regarded it as something else. Perhaps the most lucid and consecutive discussion to be found in his work is in chapter 21 of The General Theory on 'The theory of prices' (and, more especially, between pages 295 and 303). Paradoxically, however, it is rather hard to use this section for our purposes. The difficulty is that Keynes thought the proposition that inflation was due to excess demand so self-evident that he did not bother to argue it. The discussion consists of permutations of assumptions, all of which derive from a theoretical position of extreme orthodoxy. No alternative to excess-demand inflation is contemplated, let alone explored.

The form of the discussion is to put forward, as a pivot for further argument, the principle that, 'So long as there is unemployment, employment will change in the same proportion as the quantity of money; and when there is full employment, prices will change in the same proportion as the quantity of money'. ${ }^{15}$ The validity of this principle is shown to depend on five conditions. Only one of the five conditions is concerned with the 
institutional context of wage-bargaining. It is the tendency for the wageunit - or, in effect, money wages - to rise before full employment has been reached. Let me quote the relevant passage in full: 'In actual experience the wage-unit does not change continuously in terms of money in response to every small change in effective demand; but discontinuously. These points of discontinuity are determined by the psychology of the workers and by the policies of employers and trade unions'. ${ }^{16}$ In other words, the significance of the union movement is recognized. But the exercise of bargaining power depends on prior changes in 'effective demand'.

This was plainly thought to be the normal run of events. These 'discontinuities' represented 'semi-inflations' which 'have, moreover, a good deal of historical importance'. It is not surprising that Keynes saw unions as susceptible to the same economic pressures as firms or individuals. In his lifetime, the membership of the union movement was substantially reduced on two distinct occasions - between 1921 and 1924, and between 1929 and 1932. In both instances the cause was the downturn in demand. To summarize, Keynes believed there to be an interplay between institutions and economic forces. He did not believe, as the Keynesians of the 1970s sometimes appeared to do, that institutions dictate to or overwhelm these forces, and that politics always trumps economics. ${ }^{17}$

Whereas Keynes hardly ever attributed trade unions a causal role in inflation, there are in The General Theory and other places an abundance of passages in which inflation is 'a monetary phenomenon'. (The claim that inflation is 'a monetary phenomenon' is associated with the famous American economist, Professor Milton Friedman.) Indeed, on one occasion Keynes gave a definition of inflation which was stated in terms of the money supply. He did not dither between two competing modern definitions, of 'rising prices' and 'aggregate demand in excess of aggregate supply'. Instead, in his words, 'From 1914 to 1920 all countries experienced an expansion in the supply of money relative to the supply of things to purchase, that is to say Inflation. ${ }^{18}$

Moreover, the emphasis on money in the inflations of the First World War is consonant with the dominant themes of Keynes's depression economics. The more simple-minded explanations of Keynes's theory often concentrate unduly on the need for public works to raise spending. But this neglects the cause of inadequate private investment, which was too much liquidity preference or, roughly speaking, the behaviour of the demand for money. ${ }^{19}$ When savings take the form of liquid holdings (such as bank deposits) rather than illiquid holdings (like plant and machinery), the demand for goods declines and there is unemployment. The traditional answer was to lower the rate of return on liquid holdings, until savers shifted back into illiquid. But Keynes saw that, in certain extreme 
circumstances, there might be psychological and institutional barriers to a sufficient downward reduction in the rate of interest. It followed from this that monetary policy, intended to engineer changes in interest rates, could not by itself cause a recovery of demand. The potential impotence of monetary policy had to be remedied, in his words, by 'a somewhat comprehensive socialization of investment'. If investment were in state hands, it could be undertaken with larger ambitions than mere profit-maximization. In particular, it could be stepped up in order to promote higher employment.

However, if the risk that monetary policy might become impotent in a depression is one of the principal conclusions of Keynes's economics, there is no foundation for the widespread Keynesian attitude that 'money does not matter'. Keynes's writings are replete with references to the banking system and financial assets. It would be remarkable if he thought them irrelevant to problems of economic policy in normal circumstances. (Of course, the 1930s were not normal circumstances. But it should be remembered that three out of the eight historical illustrations in chapter 30 of $A$ Treatise on Money, the book which preceded The General Theory, were analyses of inflations. Keynes did think about the longer time span..$^{20}$ )

In Keynes, the monetary variable under discussion was usually the rate of interest (the price of money) rather than the money supply (its quantity). This has subsequently been a fertile and persistent source of disagreement between the Keynesians and others. The Keynesians say that no support is to be found in The General Theory or elsewhere for the mechanistic rules advocated by, for example, Milton Friedman of the Chicago School, in which the monetary variable emphasized is the quantity of money. It is true that nowhere in Keynes is there a forthright recommendation for stable growth of a monetary aggregate. But there are sections of $A$ Tract on Monetary Reform which come remarkably close to this standard monetarist position. ${ }^{21}$ (Keynes's proposal for 'a managed currency' is discussed in more detail in Essay 3, on pp. 61-3.)

Of course, Keynes was in no position to talk with confidence about fluctuations in money supply growth, because he lived in an age before full statistics were available. The rate of interest, on the other hand, was something known and observable. There are extensive passages in $A$ Treatise on Money (1930) where Keynes was examining such measures of the money supply as he could find, and trying to identify relationships between them on the one hand and nominal asset prices and national income on the other. The two most interesting cases were in Britain in the decade after the First World War and in the USA between 1925 and $1930 .{ }^{22}$ There were mismatches between changes in the money supply and nominal national income changes, which, interestingly, he attributed to 'lags' between 'profit' and 'income inflations'. The discussion in these 
pages is a fascinating attempt to understand the transmission mechanism of monetary policy.

Keynes's tendency to focus on the price of money, rather than its quantity, may also have reflected his involvement in insurance and fund management. He was active in City finance and speculation throughout the 1920 s and 1930s, and to some extent looked at the monetary situation in the same way as bankers and brokers. Bankers, who have to arrange loans from day to day, think of the demand for credit as fickle and volatile, while economists, who look at a range of monetary aggregates as measured by long-run time series, regard it as continuous and stable. Bankers see interest rates, which give signals of credit availability, as the determining variable, while monetary economists have a greater tendency to watch the money supply. Keynes mostly thought in interest rate terms. But this does not mean that, in the general run of events, he distrusted the effectiveness of monetary policy as a method of changing demand, output and employment. A clear statement of his position is again to be found in $A$ Treatise on Money. The authorities have, he said, no control over individual prices (like those of cars or meat) in the economic system. Nor do they have direct control over the money supply because the central bank must act as lender of last resort. But they do determine one price, 'the rate of discount', or the rate of interest. It is this which gives them leverage over the system as a whole. ${ }^{23}$

\section{III}

One final point, which is perhaps decisive in refuting the Keynesians, needs to be made: it is that when Britain was confronted with nasty outbreaks of inflation during his lifetime, Keynes supported policies of a traditional, demand-restrictive nature. It has been too readily assumed that the years from 1914 to 1945 were of prolonged and unremitting depression, characterized by falling or stable prices, and that Keynes was therefore never called upon to offer advice on the control of inflation. This is quite wrong. In early 1920, Britain was in the midst of an inflationary boom of proportions which have never been paralleled before or since. (Conditions in 1973 and 1974 were, in some respects, rather similar.) In both 1918 and 1919 money wages soared by nearly 30 per cent a year, and even by February 1920 there seemed no sign of an early release from the grip of the price explosion which had inevitably followed.

The Chancellor of the Exchequer, Austen Chamberlain, asked for an interview with Keynes to obtain his opinion on the right course of action. Chamberlain later summarized his impression of the interview as, ' $\mathrm{K}$. 
would go for a financial crisis (doesn't believe it would lead to unemployment). Would go to whatever rate is necessary - perhaps 10 per cent - and would keep it at that for three years' ${ }^{24}$ Shortly afterwards Keynes prepared a 15-point memorandum in which he amplified his advice. Perhaps its most startling feature is the similarity between the economic issues of early 1920 and those of late 1974, and only a little less startling is Keynes's set of recommendations to deal with the problems. He wanted stiff and harsh deflation.

Is this document an aberration? Would Keynes have retracted it with the benefit of hindsight and of the breakthroughs in economic thought he pioneered in the 1930s? In 1942 he was shown his 1920 memorandum. He was not in the least repentant. Far from thinking his position too iconoclastic, he acknowledged that other economists at the time had thought exactly the same and that they had been equally right. To quote:

As usual the economists were found to be unanimous and the common charge to the contrary without foundation! I feel myself that I should give today exactly the same advice that I gave then, namely a swift and sharp dose of dear money, sufficient to break the market, and quick enough to prevent at least some of the disastrous consequences that would then ensue. In fact, the remedies of the economists were taken, but too timidly. ${ }^{25}$

There is no need to go any further. The argument could be reinforced by an analysis of Keynes's views of war finance, but there is already enough evidence to validate the main contentions of this essay. There was almost nothing in Keynes's writings, philosophy or work which coincided with the views on inflation policy held by the British Keynesians of the 1960s and 1970s. They favoured direct government interference to keep prices down; he scorned price regulation as ineffective and harmful. They considered inflation to be a cost-push phenomenon; he never envisaged it as anything but a phenomenon of excess demand. They dismissed monetary policy; he thought the one sure answer to inflationary excess was 'a swift and severe dose of dear money'.

Were the Keynesians really loyal followers of Keynes?

\section{NOTES}

1. The best-known Keynesians in this country in the 1960s and 1970s were Sir Roy Harrod, Lord Kahn, Lord Kaldor and Joan Robinson. Kahn, Kaldor and Mrs Robinson stayed at Cambridge, but Sir Roy Harrod taught at Oxford for most of his academic career. Although Cambridge was the home of Keynesianism, many economists in universities throughout England professed Keynesian affiliations, and it is, perhaps, misleading to locate it too precisely in geographical terms. Throughout the essay, Keynesianism 
means the body of beliefs of this group of economists, and the Keynesians were these economists. A distinction is therefore being drawn between Keynesian economics and Keynes's economics. A similar distinction was made in A. Leijonhufvud's On Keynesian Economics and the Economics of Keynes (New York: Oxford University Press, 1968), although Leijonhufvud was concerned with the whole body of Keynes's economics whereas I am only interested in his work on inflation.

2. Roger Opie, 'The political consequences of Lord Keynes', in D.E. Moggridge (ed.), Keynes: Aspects of the Man and his Work (London: Macmillan, 1974), p. 87.

3. Joan Robinson, Economic Philosophy (Harmondsworth: Penguin, 1962), p. 131.

4. In 1990 the Institute of Economic Affairs published British Economic Opinion: A Survey of a Thousand Economists by M. Ricketts and E. Shoesmith. When asked for their views on the proposition 'Wage-price controls should be used to control inflation', 5.4 per cent of respondents 'agreed strongly' and 28.3 per cent agreed 'with reservations', while 14.4 per cent neither agreed nor disagreed. However, attitudes towards wage and price controls would undoubtedly have been more positive 15 or 20 years earlier.

5. Sir Roy Harrod, 'Keynes's theory and its applications', in Moggridge (ed.), Keynes: Aspects, pp. 9-10; and Opie, in Moggridge (ed.), Keynes: Aspects, p. 86. The 1970s saw suggestions that there was such a thing as a 'just price' and that 'social considerations' should enter into price determination. See A. Jones, The New Inflation (London: Andre Deutsch, 1973), particularly chapters 5 and 6.

6. Sir Roy Harrod in Moggridge (ed.), Keynes: Aspects, p. 9.

7. J.M. Keynes, The General Theory of Employment, Interest and Money (London: Macmillan, Papermac edition, 1964, originally published 1936), pp. 41-3. See, particularly, the footnote on pp. 42-3.

8. Sir John Hicks, The Crisis in Keynesian Economics (Oxford: Blackwell, 1974), pp. 59-60.

9. Sir Roy Harrod in Moggridge (ed.), Keynes: Aspects, p. 9. Other examples: 'It would be most inappropriate for me to stand up here and tell you what Keynes would have thought. Goodness knows he would have thought of something much cleverer than I can think of' (pp. 8-9); and: 'I do not think we can tackle it without direct interference. They do seem to be doing this rather more effectively in America now than here having tribunals, boards, call them what you will, responsible for fixing maximum price increases. I am sure we have got to come to that, and, as our Chairman very kindly hinted, I had a letter in The Times on this very subject yesterday' (p. 10).

10. J.M. Keynes, How to Pay for the War (1940), which originally appeared as articles in The Times on 14 and 15 November 1939, with pp. 61-70 reprinted in R.J. Ball and P. Doyle (eds), Inflation (Harmondsworth: Penguin, 1969), pp. 21-7.

11. J.M. Keynes, 'Liberalism and labour' (1926), reprinted in Essays in Persuasion (London: Macmillan, 1931), p. 341.

12. An amusing footnote on this theme appeared on pp. 70-71 of D.E. Moggridge (ed.), Keynes: Aspects of the Man and his Work. It was at Joan Robinson's expense. She had supported the notion that 'Maynard had never spent the 20 minutes necessary to understand the theory of value', sublimely unaware that as a matter of fact (as is clear from one of the notes to her publisher) he had acted as referee to her very book on the subject.

13. E. Johnson and D.E. Moggridge (eds), The Collected Writings of John Maynard Keynes, vol. II, The Economic Consequences of the Peace (London: Macmillan for the Royal Economic Society, 1971, originally published in 1919), pp. 151-2.

14. Keynes, Essays in Persuasion, p. 284. The alternative of import restrictions was the one preferred in the context of the passage quoted, but Keynes was in favour of a devaluation if it was politically possible.

15. Keynes, General Theory, p. 296.

16. Keynes, General Theory, p. 301.

17. The frailty of institutions in the face of economic imperatives was one theme of G.A. Dorfman, Wage Politics in Britain (London: Charles Knight, 1974). See, particularly, chapter 2 on the inter-war period.

18. Keynes, Essays in Persuasion, p. 60. 
19. There is a fascinating discussion of the notion of liquidity preference, and its connection with investment flexibility, in the second part of Sir John Hicks, The Crisis in Keynesian Economics.

20. Johnson and Moggridge (eds), The Collected Writings of John Maynard Keynes, vol. VI, A Treatise on Money: The Applied Theory of Money (London: Macmillan for the Royal Economic Society, 1971, originally published in 1930), pp. 132-86.

21. Johnson and Moggridge (eds), The Collected Writings of John Maynard Keynes, vol. IV, A Tract on Monetary Reform (London: Macmillan for the Royal Economic Society, 1971 , originally published in 1923), pp. 141-8.

22. Keynes, Treatise, pp. 155-61 and pp. 170-75.

23. Keynes himself put 'direct' in italics (p. 189) of the Treatise, presumably because he thought that a rise in the price of money would cause people to economize on its use and, therefore, the authorities could indirectly control the money supply. The belief that a central bank should not hold down the money supply directly, because it has the lenderof-last-resort function, is a very typical banker's attitude. Incidentally, it is one reason why Friedmanite economists and central bankers often do not see eye to eye.

24. S. Howson, "A dear money man"? Keynes on monetary policy, 1920', The Economic Journal, June 1973, p. 458.

25. Howson, "A dear money man", p. 461. 